Int. J. Electrochem. Sci., 12 (2017) $3840-3858$

\title{
Development of Cross linked Chitosan/Alginate Polyelectrolyte Proton Exchanger Membranes for Fuel Cell Applications
}

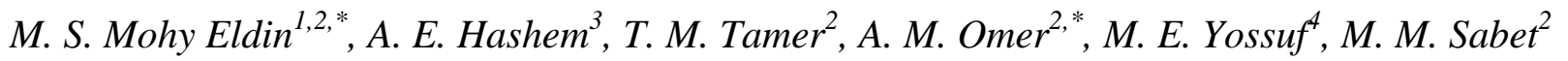 \\ ${ }^{1}$ Chemistry Department, Faculty of Science, University of Jeddah, Asfan, P. O. Box: 80203, Jeddah \\ 21589, Saudi Arabia \\ ${ }^{2}$ Polymer Materials Research Department, Advanced Technology and New Materials Research \\ Institute, SRTA-City, New Borg El-Arab City 21934, Alexandria, Egypt \\ ${ }^{3}$ Organic Chemistry Department, Faculty of Science, Ain-Shams University, Cairo, Egypt \\ ${ }^{4}$ Computer-Based Engineering Applications Department, Informatics Research Institute, MUCSAT, \\ New Borg El-Arab City 21934, Alexandria, Egypt \\ *E-mail: m.mohyeldin@mucsat.sci.eg, Ahmedomer_81@yahoo.com
}

doi: $10.20964 / 2017.05 .45$

Received: 31 August 2016 / Accepted: 9 December 2016 / Published: 12 April 2017

In this study, chitosan (CS) was chemically crosslinked with an activated-low molecular weight alginate biopolymer (Alg) with different molar ratios. The activation process of alginate was achieved using glutaraldehyde (GA) as a covalent crosslinker to obtain CS/Alg-GA crosslinked membrane as a potential polyelectrolyte for fuel cell applications. Various instrumental characterizations such as FTIR, TGA, SEM, and tensile machine were applied to verify the changes in the chemical structure, thermal stability, the morphological structure and mechanical properties respectively. Furthermore, both thermal stability and mechanical properties were also investigated. The results were obtained and compared with that obtained using ionic crosslinked CS/Alg membranes. Maximum ion exchange capacity (IEC) was established $(5.96 \mathrm{meq} / \mathrm{g})$ using CS/Alg-GA with molar ratio (4/1), while, only $3.47 \mathrm{meq} / \mathrm{g}$ was obtained in case of ionic crosslinked CS/Alg with the same molar ratio. The interaction with water and methanol were investigated via methanol and water uptake studies. Results showed that the covalent crosslinked CS/Alg-GA membranes have a low permeability for methanol ranged from $2.179 \times 10^{-9}$ to $2.5 \times 10^{-10} \mathrm{~cm}^{2} / \mathrm{s}$ compared to that of Nafion membranes $\left(1.14 \times 10^{-9} \mathrm{~cm}^{2} / \mathrm{s}\right)$. Above all, simplicity of the used preparation method and the cost reduction potentials of covalent crosslinked CS/Alg-GA membranes promote their use for DMFC applications as proton exchanger membranes.

Keywords: Fuel cell, Chitosan, Alginate, Covalent crosslinking, Electrolyte membrane. 
(C) 2017 The Authors. Published by ESG (www.electrochemsci.org). This article is an open access article distributed under the terms and conditions of the Creative Commons Attribution license (http://creativecommons.org/licenses/by/4.0/). 